\begin{tabular}{|l|lll|}
\hline & Journal : Small 10531 & Dispatch : 22-4-2013 & Pages : 14 \\
& Article No. : 490 & $\square$ LE & $\square$ TYPESET \\
MS Code : BIOC4512 & $\checkmark$ CP & $\checkmark$ DISK \\
\hline
\end{tabular}

\title{
2 Ungulate browsing shapes climate change impacts 3 on forest biodiversity in Hungary
}

\author{
4 Krisztián Katona • Márton Kiss • Norbert Bleier • János Székely • \\ 5 Mariann Nyeste • Vera Kovács • Attila Terhes • Áron Fodor • \\ 6 Tamás Olajos $\cdot$ Ervin Rasztovits $•$ László Szemethy
}

Abstract Climate change can result in a slow disappearance of forests dominated by less drought-tolerant native European beech (Fagus sylvatica) and oak species (Quercus spp.) and further area expansion of more drought-tolerant non-native black locust (Robinia pseudoacacia) against those species in Hungary. We assumed that the shift in plant species composition was modified by selective ungulate browsing. Thus, we investigated which woody species are selected by browsing game. We have collected data on the species composition of the understory and the browsing impact on it in five different Hungarian even-aged forests between 2003 and 2005. Based on these investigations the non-native Robinia pseudoacacia living under more favourable climatic conditions was generally preferred (Jacobs' selectivity index: $\mathrm{D}=0.04 \pm 0.77$ ), while the native Fagus sylvatica and Quercus spp. (Q. petraea, $Q$. robur), both more vulnerable to increasing aridity, were avoided $(D=-0.37 \pm 0.11 ;-0.79 \pm 0.56 ;-0.9 \pm 0.16$; respectively) among target tree species. However, economically less or not relevant species, e.g. elderberry (Sambucus spp.), blackberry (Rubus spp.) or common dogwood (Cornus sanguinea) were the most preferred species $(D=0.01 \pm 0.71 ;-0.12 \pm 0.58 ;-0.2 \pm 0.78$, respectively). Our results imply that biodiversity conservation, i.e. maintaining or establishing a multi-species understory layer, can be a good solution to reduce the additional negative game impact on native target tree species suffering from drought. Due to preference for Robinia pseudoacacia selective browsing can decelerate the penetration of this species into native forest habitats. We have to consider the herbivorous pressure of ungulates and their feeding preferences in planning our future multifunctional forests in the light of climate change impacts.

A1 K. Katona $(\bowtie) \cdot$ M. Kiss · N. Bleier · J. Székely · M. Nyeste · V. Kovács · A. Terhes · Á. Fodor .

A2 T. Olajos - L. Szemethy

A3 Institute for Wildlife Conservation, St. István University, Páter K. Street 1, Gödöllő 2100, Hungary

A4 e-mail: katonak@ns.vvt.gau.hu

A6 Institute of Environmental and Earth Sciences, University of West Hungary, Sopron, P.O.B. 132, 9400, Hungary 


\begin{tabular}{|l|lll|}
\hline & Journal : Small 10531 & Dispatch : 22-4-2013 & Pages : 14 \\
& Article No. : 490 & $\square$ LE & $\square$ TYPESET \\
MS Code : BIOC4512 & $\checkmark \mathrm{CP}$ & $\checkmark$ DISK \\
\hline
\end{tabular}

Biodivers Conserv

Keywords Red deer · Black locust · Preference · Even-aged forest · Understory · Climate

adaptation

\section{Introduction}

34

35

36

37

38

39

40

41

42

43

44

45

46

47

48

49

50

51

52

53

54

55

56

57

58

59

60

61

62

63

64

65

66

67

Global climate change is now evident (IPCC 2007) from observations of rising mean global temperature and greater number and higher intensity of weather extremes (e.g. droughts). These changes will have profound impacts on the biodiversity, conservation and management of Central European forest ecosystems (Milad et al. 2011). Hungary is situated at the lower distribution end of all native stand-forming tree species, where the limiting factor is water availability (Mátyás et al. 2009). Along the zone of this xeric limit the climatic forecasts become more uncertain (Mátyás 2010). In Hungary the probability and severity (warmer and dryer) of droughts is projected to be higher than it was during the end of the 20th century (Gálos et al. 2008). Consequently, the ecological vulnerability of this region to climatic changes is high (SEG 2007).

The total forest cover of Hungary is $20.7 \%$; most of it $(>90 \%)$ is managed by clearcutting. The most important forest tree species for forest management are the native sessile and pedunculate oak (Quercus petraea and Q. robur, $20.8 \%$ of the forested areas), European beech (Fagus sylvatica) $(5.9 \%$ ), and the most widespread non-native black locust (Robinia pseudoacacia, $24 \%$ ) (Wisnovszky 2011). Species distribution models show considerable agreement in the dramatic decrease of climatic suitability for the main native target tree species of forest management, Fagus sylvatica and Quercus petraea in the coming decades in Hungary (Berki et al. 2009; Czúcz et al. 2011). Even the mildest expected scenario of climate change is similar in magnitude to a whole vegetation zone difference; the temperature and precipitation change might trigger the shift of zones (Mátyás and Czimber 2000). Regarding the stands in zonal position, 56-99\% of present-day Fagus sylvatica forests and 82-100\% of Quercus petraea forests might be outside their present bioclimatic niche by 2050 (Czúcz et al. 2011). The latest and the most extreme drought period occurred in the first years of the 21st century causing large scale Fagus sylvatica mortality along the lower distribution limit in South-west Hungary (Lakatos and Molnár 2009).

Introduced drought-tolerant species could gain ground against native tree species because of the projected climatic changes in the future. According to the Hungarian National Forest Strategy, the proportion of the forested areas will increase to $27 \%$ in the next decades (FVM 2008). Although the plans suggest establishing near-natural forests of native tree species, short-term economic interests often lead to intensively managed forest habitats. For private forest owners, who possess more than $50 \%$ of the lowland forests in Hungary (Wisnovszky 2011), plantation of Robinia pseudoacacia monocultures seems to be the most profitable choice in many cases. This species grows very rapidly (25-30 years to cut), survives droughts and severe winters and tolerates infertile and acidic soils. As it is also useful for bee-keeping or producing high-quality livestock feed, it can serve as a multi-purpose tree species for temperate climates (Barrett et al. 1990). However, Robinia pseudoacacia is a highly invasive, nitrogen-fixing tree favouring the growth of nitrophilous plant species and contributing to lower plant species diversity. Therefore, the expected intensive area expansion of Robinia pseudoacacia in Hungary (caused by its use in new plantations and the penetration of the species into climax forest stands) can be an additional factor in causing the elimination of native tree species from a part of their potential range and the decrease of forest biodiversity. 


\begin{tabular}{|l|lll|}
\hline & Journal : Small 10531 & Dispatch : 22-4-2013 & Pages : 14 \\
& Article No. : 490 & $\square$ LE & $\square$ TYPESET \\
MS Code : BIOC4512 & $\checkmark$ CP & $\checkmark$ DISK \\
\hline
\end{tabular}

Biodivers Conserv

Climate change also impacts ungulate populations; the actual fluctuations in climate will impose a greater instability in their population dynamics (Apollonio et al. 2010). However, in the past decades we experienced the expansion and substantial increase of deer species throughout Europe (Burbaité and Csányi 2009; Milner et al. 2006). Expansion of deer (red deer, Cervus elaphus, roe deer, Capreolus capreolus and fallow deer, Dama dama) populations is clearly visible in Hungary (Csányi and Lehoczki 2010). Growing deer populations have serious impacts on forested and agricultural areas (Côté et al. 2004; Gill and Beardall 2001; Putman and Moore 1998). Selective browsing of ungulates can modify the interactions between competing species and thus change the overall pattern of plant diversity in forests. Forest trees are constantly under attack by a set of herbivorous animals. Under normal conditions they are generally able to either survive those effects or fend them off. But trees under abnormal temperature or moisture stress are less resilient against attack and may suffer more losses (Winnett 1998). Therefore, selective ungulate browsing is a potential factor shaping woody species distribution and composition primarily determined by climate change impacts.

Herbivory may both strengthen and counteract the effects of changing climate on tree species distribution (Cairns and Moen 2004). A less intensively browsed, more droughttolerant tree species may have an opportunity for expansion to other areas currently dominated by tree species suffering from both drought- and ungulate-induced damage (Herrerro et al. 2012). To evaluate the joint effects of climate change and large herbivores on forest species composition, a ranking order of woody species based on their preference by browsing ungulates is essential (Didion et al. 2011). However, this classification of temperate woody species in Europe is still lacking, with some rare exceptions (Boulanger et al. 2009).

The aim of our study was then to establish the order of Hungarian woody species common in even-aged forests according to their attractiveness to game browsing. On the basis of the preference order we investigated whether the pattern of selective ungulate browsing generally predicts an additional negative impact to climate change on area loss of native drought-sensitive tree species (Fagus sylvatica and Quercus spp.) or on the expansion of non-native drought-tolerant tree species (Robinia pseudoacacia). Therefore, our main question was which woody species are mainly selected by game browsing: (1) native target tree species more vulnerable to increasing aridity, (2) non-native less droughtsensitive target tree species, (3) other economically non-relevant woody species.

\section{Methods}

\section{Study areas}

The study was carried out in five different areas of traditional even-aged forest management system in Hungary (Hajósszentgyörgy, 46 $24^{\prime} \mathrm{N}, 1^{\circ} 07^{\prime} \mathrm{E}$; Gemenc (Keselyüs), $46^{\circ} 20^{\prime} \mathrm{N}, 18^{\circ} 51^{\prime} \mathrm{E}$; Segesd, $46^{\circ} 21^{\prime} \mathrm{N}, 17^{\circ} 20^{\prime} \mathrm{E}$; Zselic (Kardosfa), $46^{\circ} 14^{\prime} \mathrm{N}, 17^{\circ} 46^{\prime} \mathrm{E}$ and Felsőtárkány, $47^{\circ} 58^{\prime} \mathrm{N}, 20^{\circ} 25^{\prime} \mathrm{E}$ ) (Fig. 1; Table 1). Although forests were regenerated by clearcuts in all study areas, there were strong differences in the intensity of forest management practices (e.g. clearcutting in one or more steps; smaller or larger clearcut areas; natural or artificial regenerations, rare or frequent use of fences against game damage, monospecies or more diverse woody species composition; rare or frequent shrub and dead wood removal, etc.). 


\begin{tabular}{|l|lll|}
\hline & Journal : Small 10531 & Dispatch : 22-4-2013 & Pages : 14 \\
& Article No. : 490 & $\square$ LE & $\square$ TYPESET \\
MS Code : BIOC4512 & $\vee$ CP & $\checkmark$ DISK \\
\hline
\end{tabular}

Biodivers Conserv

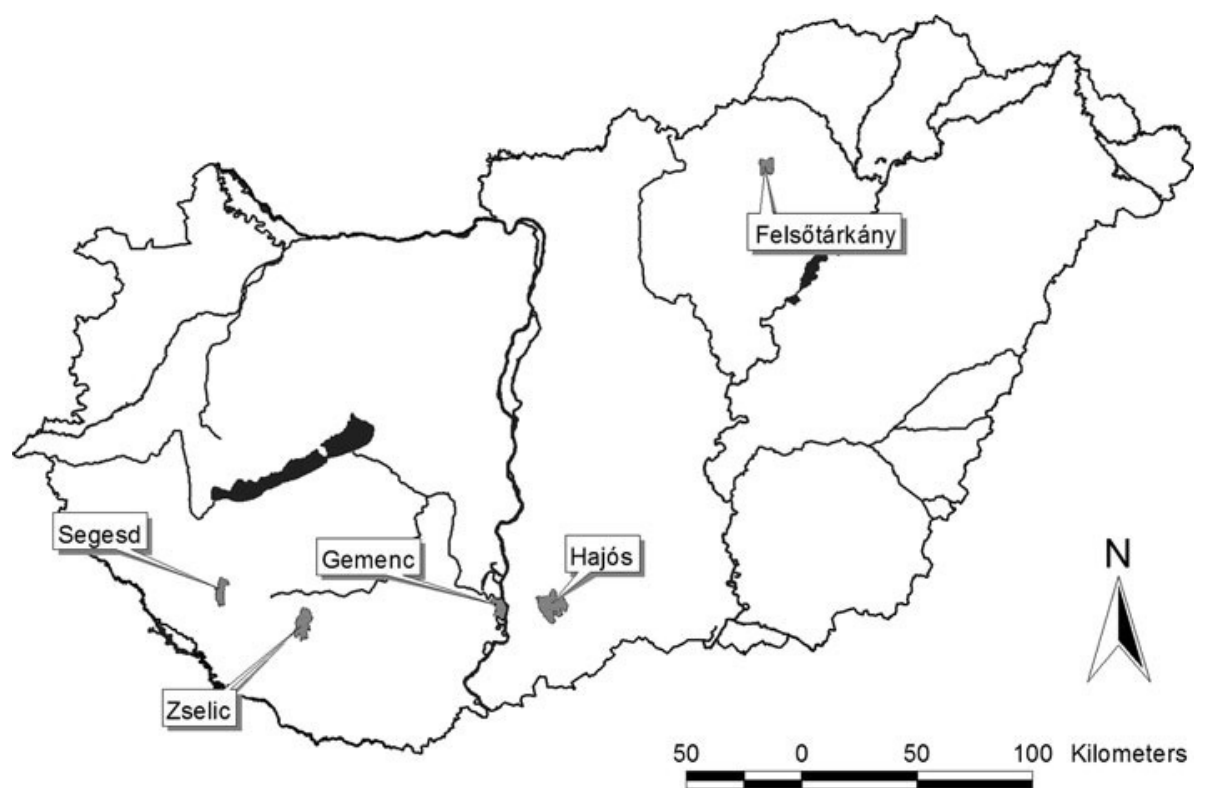

Fig. 1 The locality of the study areas. Grey patches show the forested areas, where the field measures were carried out. Rivers and large lakes of Hungary are also indicated

According to the abovementioned differences, Hajósszentgyörgy is an intensively managed area on poor sandy soil of the Hungarian Great Plain afforested with Scots and black pine (Pinus sylvestris and P. nigra) and Robinia pseudoacacia about 50 years ago. This area is mainly occupied by artificial monospecies plantations where non-native woody and herbaceous species are common. Gemenc is a famous floodplain area of the Danube River with native poplar (Populus spp.) and Quercus robur-Fraxinus spp. (ash species) forests. This is a highly diverse forested area located in Duna-Dráva National Park. Natural regeneration methods are used primarily, but artificial regeneration with native and sometimes non-native species (e.g. hybrid Populus spp.) also exists. Segesd is in a hilly region covered mainly by Carpinus betulus (common hornbeam)-Quercus robur forest stands. This area is a heterogeneous and diverse forest mosaic established by a cautious clearcutting method felling trees only in small areas. Forest regeneration is based on artificial methods; acorn sowing is especially preferred. Zselic is a landscape protection area in a mountainous region dominated by Carpinus betulus-Quercus petraea and Tilia tomentosa (silver lime)-Fagus sylvatica forests. The majority of those forests (77\%) were designated for protective purposes. As a consequence nature conservation fundamentally determines forest management practices. The proportion of natural methods in forest regeneration is increasing (currently about $40 \%$ ) in that area. The Felsőtárkány region is 138 situated in the Bükk Mountains with stands composed of Carpinus betulus, Quercus 139 petraea, Q. cerris (Turkey oak) and Fagus sylvatica. Although it is a preserved area of 140 Bükk National Park, the forest management is characterized by large clearcut areas. Generally, forests in Felsőtárkány are in weak condition. They have poor understory and are hardly able to regenerate naturally.

In all areas frequent use of fences around regeneration sites to control game damage is the norm. The estimated density of different game species populations and the number of 


\begin{tabular}{|l|lll|}
\hline & Journal : Small 10531 & Dispatch : 22-4-2013 & Pages : 14 \\
Article No. : 490 & $\square$ LE & $\square$ TYPESET \\
MS Code : BIOC4512 & $\checkmark \mathrm{CP}$ & $\checkmark$ DISK \\
\hline
\end{tabular}

Biodivers Conserv

Table 1 Characteristics of the study areas

\begin{tabular}{|c|c|c|c|c|c|}
\hline & Hajósszentgyörgy & Gemenc & Segesd & Zselic & Felsőtárkány \\
\hline Altitude (m) & $110-170$ & $80-90$ & $140-190$ & $140-300$ & $180-340$ \\
\hline $\begin{array}{l}\text { Yearly } \\
\text { precipitation } \\
(\mathrm{mm})\end{array}$ & 610 & 640 & 700 & 710 & 700 \\
\hline $\begin{array}{l}\text { Yearly mean } \\
\text { temperature } \\
\left(\mathrm{C}^{\circ}\right)\end{array}$ & 10.7 & 11.1 & 9.7 & 10 & 7.5 \\
\hline Main soil types & Sandy soil & Alluvial soil & $\begin{array}{l}\text { Brown forest } \\
\text { soil, marshy } \\
\text { meadow soil }\end{array}$ & $\begin{array}{l}\text { Brown forest } \\
\text { soil }\end{array}$ & $\begin{array}{l}\text { Lithosol, } \\
\text { brown forest } \\
\text { soil }\end{array}$ \\
\hline $\begin{array}{l}\text { Main } \\
\text { vegetation } \\
\text { types }\end{array}$ & $\begin{array}{l}\text { Locust and pine } \\
\text { forests }\end{array}$ & $\begin{array}{l}\text { Poplar and oak- } \\
\text { ash forests }\end{array}$ & $\begin{array}{l}\text { Alder, } \\
\text { hornbeam- } \\
\text { oak and } \\
\text { sessile oak- } \\
\text { turkey oak } \\
\text { forests }\end{array}$ & $\begin{array}{l}\text { Hornbeam- } \\
\text { oak and } \\
\text { silver lime- } \\
\text { beech } \\
\text { forests }\end{array}$ & $\begin{array}{l}\text { Beech, } \\
\text { hornbeam- } \\
\text { oak and oak } \\
\text { forests }\end{array}$ \\
\hline $\begin{array}{l}\text { Characteristic } \\
\text { tree and } \\
\text { shrub species }\end{array}$ & $\begin{array}{l}\text { Black locust, } \\
\text { Scots and black } \\
\text { pine, western } \\
\text { hackberry, } \\
\text { hawthorn, } \\
\text { blackthorn, } \\
\text { elderberry }\end{array}$ & $\begin{array}{l}\text { Pedunculate } \\
\text { oak, white } \\
\text { and black } \\
\text { poplar, } \\
\text { boxelder } \\
\text { maple, } \\
\text { hawthorn, } \\
\text { common } \\
\text { dogwood }\end{array}$ & $\begin{array}{l}\text { Common alder, } \\
\text { pedunculate } \\
\text { and Turkey } \\
\text { oak, Scots } \\
\text { pine, } \\
\text { common } \\
\text { hornbeam, } \\
\text { blackberry }\end{array}$ & $\begin{array}{l}\text { Sessile and } \\
\text { Turkey } \\
\text { oak, } \\
\text { common } \\
\text { beech, } \\
\text { common } \\
\text { hornbeam, } \\
\text { silver lime }\end{array}$ & $\begin{array}{l}\text { Common } \\
\text { beech, } \\
\text { common } \\
\text { hornbeam, } \\
\text { sessile and } \\
\text { Turkey oak, } \\
\text { field maple, } \\
\text { hawthorn }\end{array}$ \\
\hline Area size (ha) & 14600 & 9400 & 6600 & 10000 & 12100 \\
\hline $\begin{array}{l}\text { Occurring large } \\
\text { herbivore } \\
\text { species }\end{array}$ & $\begin{array}{l}\text { Red deer, roe } \\
\text { deer }\end{array}$ & $\begin{array}{l}\text { Red deer, roe } \\
\text { deer }\end{array}$ & $\begin{array}{l}\text { Red deer, roe } \\
\text { deer, fallow } \\
\text { deer, mouflon }\end{array}$ & $\begin{array}{l}\text { Red deer, roe } \\
\text { deer, } \\
\text { fallow } \\
\text { deer, } \\
\text { mouflon }\end{array}$ & $\begin{array}{l}\text { Red deer, roe } \\
\text { deer, } \\
\text { mouflon }\end{array}$ \\
\hline $\begin{array}{l}\text { Time of } \\
\text { investigations }\end{array}$ & $\begin{array}{l}\text { February, May, } \\
\text { July, October of } \\
\text { 2004; February } \\
\text { of } 2005\end{array}$ & $\begin{array}{l}\text { March, June, } \\
\text { July, October } \\
\text { of 2004; } \\
\text { January of } \\
2005\end{array}$ & $\begin{array}{l}\text { February, May, } \\
\text { July, October } \\
\text { of 2004; } \\
\text { February of } \\
2005\end{array}$ & $\begin{array}{l}\text { June, July, } \\
\text { October of } \\
2004 ; \\
\text { February, } \\
\text { May of } \\
2005\end{array}$ & $\begin{array}{l}\text { March, May, } \\
\text { July, } \\
\text { October of } \\
\text { 2003; March } \\
\text { of } 2004\end{array}$ \\
\hline $\begin{array}{l}\text { Number and } \\
\text { length of } \\
\text { transects }\end{array}$ & $\begin{array}{l}3 \text { transects of } 2.8 \\
3.2 \text { and } 3.6 \mathrm{~km}\end{array}$ & $\begin{array}{l}3 \text { transects of } \\
2.5,3 \text { and } \\
4.5 \mathrm{~km}\end{array}$ & $\begin{array}{l}3 \text { transects, } \\
\text { each of } \\
3-3.5 \mathrm{~km}\end{array}$ & $\begin{array}{l}2 \text { transects, } \\
\text { each of } \\
8 \mathrm{~km}\end{array}$ & $\begin{array}{l}2 \text { transects of } \\
3.8 \text { and } \\
2.65 \mathrm{~km}\end{array}$ \\
\hline
\end{tabular}

145 shot animals reported by game management units utilizing our study areas in 2004 are 146 shown in Table 2 (based on the National Game Management Database of Hungary).

147 Field data collection

148 Our seasonal investigations were carried out between 2003 and 2005. Two or three per149 manent parallel sampling lines (between 6.5 and $16 \mathrm{~km}$ in total length for an area) were 150 designated in each of the areas. Those transects were laid to obtain a representative sample 151 of the understory based on the information on forest vegetation in local forest and wildlife 152 management plans. The number of sampling points investigated along these transects in an 


\begin{tabular}{|l|llll|}
\hline & Journal : Small 10531 & Dispatch : 22-4-2013 & Pages : 14 \\
& Article No. : 490 & $\square$ LE & $\square$ TYPESET \\
\hline
\end{tabular}

Biodivers Conserv

Table 2 Population densities (individuals/100 ha) of different game species calculated from the reported number of estimated and shot animals in the different study areas in 2004

\begin{tabular}{lllllll}
\hline Species & $\begin{array}{l}\text { Population density } \\
\text { (ind./100 ha) }\end{array}$ & Hajós & Gemenc & Segesd & Zselic & Felsötárkány \\
\hline \multirow{2}{*}{ Red deer } & Estimated & 5.99 & 13.62 & 3.48 & 5.80 & 4.38 \\
& Shot & 2.96 & 4.89 & 3.05 & 5.59 & 2.24 \\
\multirow{2}{*}{ Roe deer } & Estimated & 4.42 & 2.71 & 1.82 & 4.30 & 3.31 \\
& Shot & 1.01 & 0.85 & 1.05 & 2.28 & 1.35 \\
\multirow{2}{*}{ Fallow deer } & Estimated & 0 & 0 & 0.61 & 0.45 & 0 \\
& Shot & 0 & 0 & 0.50 & 0.14 & 0 \\
\multirow{3}{*}{ Mouflon } & Estimated & 0 & 0 & 0.61 & 0.25 & 1.65 \\
& Shot & 0 & 0 & 0 & 0.04 & 0.87 \\
\multirow{2}{*}{ Wild boar } & Estimated & 1.58 & 11.65 & 1.52 & 2.30 & 3.80 \\
& Shot & 1.12 & 12.54 & 2.38 & 1.97 & 5.40
\end{tabular}

Data derives from the game management units utilizing our study areas (based on the National Game Management Database)

153

154

155

156

157

158

159

160

161

162

163

164

165

166

167

168

169

170

171

172

173

174

175

176

177

178

area in a single period was always between 150 and 300 . Sampling points were not fixed to permanent places along transects and the starting point was randomly selected.

To obtain comparable results, the measures were carried out using the same field method in every area. The method was elaborated and practised by seasonal samplings before the study. The field data collection was accomplished at $50 \mathrm{~m}$ intervals along the transects. In the Felsőtárkány area additional measures were taken at ten meters in every fourth section of $50 \mathrm{~m}$, because of the scarce understory.

In each area we estimated the woody species composition of available food supply and the relative utilisation of those species available. At the sampling points we counted the number of sprouts of all woody species available and accessible to large herbivores and the number of browsed ones in the understory layer. We had four height categories: between 0 and 50, 50 and 100, 100 and 150, 150 and $200 \mathrm{~cm}$ from the ground surface. We counted the number of sprouts available and browsed in a three-dimensional sample unit of $50 \mathrm{~cm}$ high, $50 \mathrm{~cm}$ wide and $30 \mathrm{~cm}$ deep within all vertical levels. Four sampling units placed on top of each other at every sampling point made it possible for us to count sprouts easily and reliably. Generally woody plants were identified to species, but in some cases only the genus was registered. Based on our earlier observations on herbivore browsing, one sprout item was defined as the final ramification of the plant individual, which is longer than $3 \mathrm{~cm}$ and obtains leaves in the vegetation period. The only exception was blackberry (Rubus spp.), where the compound leaves were also identified as the subject unit of browsing because the number of browsing events on the elongated stems was not possible to estimate reliably. We registered only the relatively fresh damage caused by ungulates. It was determined by the shape, pattern and colour of the damaged plant surface. We were not able to distinguish which ungulate species caused the damage. However, the dominance of red deer in these areas suggests that this species was the main consumer.

Data analysis

From the field data we determined the availability and utilisation of all woody species in every study area in every season. To decide whether a species was frequent or rare in the 


\begin{tabular}{|l|lll|}
\hline & Journal : Small 10531 & Dispatch : 22-4-2013 & Pages : 14 \\
& Article No. : 490 & $\square$ LE & $\square$ TYPESET \\
MS Code : BIOC4512 & $\checkmark \mathrm{CP}$ & $\checkmark$ DISK \\
\hline
\end{tabular}

Biodivers Conserv

181 understory and was preferred or avoided by ungulate browsing we ran $\chi^{2}$ goodness of fit 182 tests followed by Bonferroni procedures according to the description by Neu et al. (1974) 183 and Byers et al. (1984).

After the statistical analyses we compared for each species in each area the proportion of the number of occasions (seasons) when the given species was frequent/rare/nonsignificant (not frequent and not rare) and preferred/avoided/nonsignificant (not preferred and not avoided). As the relative occurrence-and also the food quality provided (see e.g. Mátrai et al. 2002) — of the understory plant species can vary significantly throughout the year, we considered each season in the same area as a new basis for investigation of browsing selectivity.

After qualifying woody species by dividing them into categories "preferred" and "avoided", we quantified browse selection by calculating the value of Jacobs' selectivity index, D (Jacobs 1974). This index is a modification of Ivlev's electivity index, which is less sensitive to sampling errors and the variations in the relative abundance of the species (Boulanger et al. 2009). Jacobs' index was calculated according to the formula: $\mathrm{D}=(\mathrm{r}-$ $\mathrm{p}) /(\mathrm{r}+\mathrm{p}-2 \mathrm{rp})$, where $\mathrm{r}$ is the contribution of a given browse species to the total browsing and $\mathrm{p}$ is the proportion of this given browse species in the total available vegetation. $\mathrm{D}$ varies from -1 (strong avoidance) to +1 (strong preference), and values close to zero indicate that the habitat is used in proportion to its availability (Kauhala and Auttila 2010). Mean and standard deviation of Jacobs' index was determined for each species by averaging seasonal values of each area.

Finally, we synthesized all the availability-utilisation data into one database. We ranked woody species based on mean Jacobs' index values to obtain a general order of species according to their preference by browsing ungulates.

\section{Results}

206 In Hajósszentgyörgy Robinia pseudoacacia, western hackberry (Celtis occidentalis) and hawthorn (Crataegus monogyna) were the most frequent species of the understory (all of them were frequent in 5 of 5 seasonal investigations; $2.09 \pm 0.79 ; 3.66 \pm 0.91$ and $4.64 \pm 1.91$ sprouts/sampling point, respectively). In Gemenc common dogwood (Cornus sanguinea) (frequent: 5 of $5 ; 2.01 \pm 0.65$ ), Rubus spp. (4 of 5; $1.6 \pm 0.75$ ), boxelder maple (Acer negundo) ( 3 of $5 ; 1.15 \pm 0.49$ ) and Crataegus monogyna (3 of 5; $1.05 \pm 0.22)$ dominated the understory. In Segesd the dominant species of the understory were Carpinus betulus ( 5 of 5; $2.02 \pm 1.07$ ), Rubus spp. (5 of 5; $1.52 \pm 0.53$ ) and Quercus robur (4 of $5 ; 0.45 \pm 0.4$ ). In Zselic the main woody species occurring in the understory were Tilia tomentosa ( 5 of 5; $2.22 \pm 0.87$ ), Fagus sylvatica ( 4 of $5 ; 3.19 \pm 0.7$ ) Carpinus betulus (4 of $5 ; 2.62 \pm 0.91$ ) and field maple (Acer campestre) ( 4 of $5 ; 0.97 \pm 0.68)$. In Felsőtárkány Carpinus betulus ( 5 of $5 ; 1.34 \pm 0.51$ ), Acer spp. (4 of 5; $1.72 \pm 0.49$ ) and Quercus spp. (3 of 5; $0.93 \pm 0.37$ ) were the most abundant species available for ungulates.

Summarizing all the study areas (Table 3), Tilia tomentosa, Carpinus betulus and Fagus sylvatica were usually dominant species in those areas where they appeared in the vegetation. Cornus sanguinea, Acer campestre and other Acer species, Robinia pseudoacacia, Rubus spp., Celtis occidentalis, Quercus robur and Q. petraea and Tilia spp. could also become a frequent species of the understory level. In turn, Populus spp. and Pinus spp., $Q$. cerris and European privet (Ligustrum vulgare) were always identified in the understory in a low proportional occurrence. 


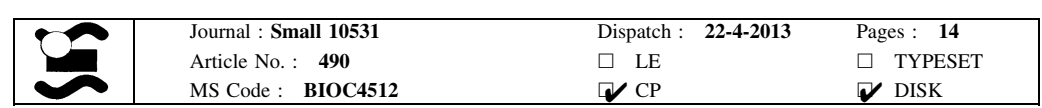

Biodivers Conserv

Table 3 Occurrence and selection of different woody species based on the data of the 5 study areas

\begin{tabular}{|c|c|c|c|c|c|c|c|}
\hline \multirow[t]{2}{*}{ Woody species } & \multirow[t]{2}{*}{$n$} & \multirow[t]{2}{*}{ Frequent $(\%)$} & \multirow[t]{2}{*}{ Rare $(\%)$} & \multirow[t]{2}{*}{ Preferred $(\%)$} & \multirow[t]{2}{*}{ Avoided (\%) } & \multicolumn{2}{|c|}{ Jacobs' index } \\
\hline & & & & & & Mean & SD \\
\hline Tilia tomentosa & 5 & 100 & 0 & 40 & 0 & 0.27 & 0.27 \\
\hline Acer negundo & 6 & 50 & 33 & 17 & 17 & 0.06 & 0.50 \\
\hline Celtis occidentalis & 7 & 71 & 29 & 14 & 29 & 0.06 & 0.71 \\
\hline Quercus rubra & 5 & 0 & 100 & 40 & 40 & 0.06 & 0.97 \\
\hline Robinia pseudoacacia ${ }^{a}$ & 14 & 43 & 36 & 29 & 36 & 0.04 & 0.77 \\
\hline Acer spp. & 8 & 50 & 50 & 25 & 13 & 0.03 & 0.54 \\
\hline Sambucus spp. & 14 & 0 & 93 & 14 & 29 & 0.01 & 0.71 \\
\hline Prunus spinosa & 14 & 7 & 86 & 7 & 29 & -0.08 & 0.67 \\
\hline Rubus spp. & 16 & 75 & 13 & 19 & 44 & -0.12 & 0.58 \\
\hline Populus spp. & 7 & 0 & 100 & 29 & 43 & -0.16 & 0.82 \\
\hline Cornus sanguinea & 11 & 45 & 55 & 36 & 45 & -0.20 & 0.78 \\
\hline Acer campestre & 9 & 44 & 44 & 33 & 33 & -0.24 & 0.55 \\
\hline Rosa canina & 14 & 0 & 79 & 14 & 36 & -0.24 & 0.67 \\
\hline Amorpha fruticosa & 6 & 0 & 100 & 17 & 50 & -0.25 & 0.86 \\
\hline Fraxinus ornus & 5 & 0 & 100 & 0 & 20 & -0.27 & 0.43 \\
\hline Ligustrum vulgare & 16 & 13 & 69 & 13 & 38 & -0.29 & 0.52 \\
\hline Pinus silvestris $^{a}$ & 5 & 0 & 100 & 0 & 60 & -0.32 & 0.93 \\
\hline Quercus cerris $^{a}$ & 7 & 0 & 100 & 0 & 57 & -0.33 & 0.85 \\
\hline Tilia spp. & 5 & 0 & 60 & 20 & 60 & -0.36 & 0.91 \\
\hline Fagus sylvatica $^{a}$ & 5 & 80 & 20 & 0 & 80 & -0.37 & 0.11 \\
\hline Quercus spp. ${ }^{a}$ & 13 & 23 & 62 & 8 & 62 & -0.38 & 0.54 \\
\hline Carpinus betulus & 15 & 93 & 7 & 7 & 47 & -0.41 & 0.48 \\
\hline Corylus avellana & 9 & 11 & 89 & 22 & 67 & -0.43 & 0.86 \\
\hline Euonymus europaeus & 6 & 0 & 100 & 0 & 67 & -0.45 & 0.88 \\
\hline Acer platanoides & 5 & 0 & 100 & 0 & 60 & -0.49 & 0.70 \\
\hline Fraxinus spp. & 10 & 10 & 80 & 10 & 60 & -0.52 & 0.51 \\
\hline Crataegus monogyna & 25 & 40 & 24 & 0 & 56 & -0.55 & 0.45 \\
\hline Tilia cordata & 5 & 20 & 60 & 0 & 60 & -0.59 & 0.57 \\
\hline Alnus glutinosa & 7 & 14 & 57 & 14 & 71 & -0.67 & 0.65 \\
\hline Ulmus spp. & 14 & 0 & 86 & 0 & 71 & -0.69 & 0.63 \\
\hline Ailanthus altissima & 5 & 0 & 100 & 0 & 80 & -0.76 & 0.53 \\
\hline Quercus petraea ${ }^{a}$ & 7 & 29 & 57 & 0 & 86 & -0.79 & 0.56 \\
\hline Quercus robur ${ }^{a}$ & 6 & 67 & 33 & 0 & 100 & -0.90 & 0.16 \\
\hline Berberis vulgaris & 6 & 0 & 83 & 0 & 83 & -0.92 & 0.20 \\
\hline
\end{tabular}

Proportion of cases a species was frequent or rare and preferred or avoided and Jacobs' selectivity index (mean $\pm \mathrm{SD}$ ) for all species is shown. Species found at least in five cases are listed. Ranking is based on Jacobs' index (decreasing order by the mean value)

$n$ number of cases

a Actual target tree species in Hungary

226 In Hajósszentgyörgy the most preferred species were the dominant Robinia pseudo227 acacia (preferred in 3 of 5 investigations; $\mathrm{D}=0.2 \pm 0.72$ ) and the rare elderberry 228 (Sambucus nigra) (preferred: 2 of 5 and never avoided; $\mathrm{D}=0.56 \pm 0.33$ ). Ligustrum 


\begin{tabular}{|l|lll|}
\hline & Journal : Small 10531 & Dispatch : 22-4-2013 & Pages : 14 \\
& Article No. : 490 & $\square$ LE & $\square$ TYPESET \\
MS Code : BIOC4512 & $\checkmark \mathrm{CP}$ & $\checkmark$ DISK \\
\hline
\end{tabular}

Biodivers Conserv

vulgare, dog rose (Rosa canina) and Quercus spp. were preferred on one occasion (D = $0.27 \pm 0.65 ; \quad-0.53 \pm 0.94 ; \quad-0.3 \pm 0.67$, respectively). The prevalent Crataegus monogyna and the infrequent tree of heaven (Ailanthus altissima) and Pinus spp. were avoided in most cases $(\mathrm{D}=-0.67 \pm 0.21 ;-0.76 \pm 0.53 ;-0.51 \pm 0.83$, respectively).

In Gemenc the most attractive species for browsing were the regularly occurring Cornus sanguinea $(\mathrm{D}=0.44 \pm 0.21)$ and in some cases the scarce Populus spp., Fraxinus spp. and Acer spp. ( $\mathrm{D}=0.17 \pm 0.71 ;-0.39 \pm 0.6 ;-0.23 \pm 0.53$, respectively). Crataegus monogyna and Quercus spp. species were always avoided similarly to Hajósszentgyörgy ( $\mathrm{D}=-0.94 \pm 0.14 ;-1 \pm 0$, respectively). Rubus spp. were never preferred and generally avoided $(\mathrm{D}=-0.29 \pm 0.51)$.

In Segesd the browsing preferences were irregular and occasionally revealed preference for Celtis occidentalis $(\mathrm{D}=0.92 \pm 0.02)$, European hazel (Corylus avellana) $(\mathrm{D}=-$ $0.3 \pm 0.96)$, Rubus spp. ( $\mathrm{D}=0.09 \pm 0.43)$, Acer spp. $(\mathrm{D}=0.1 \pm 0.99)$, alder (Alnus glutinosa) $(\mathrm{D}=-0.54 \pm 0.74)$, lime species (Tilia spp.) $(\mathrm{D}=-0.36 \pm 0.91)$ and $R o$ binia pseudoacacia $(\mathrm{D}=-0.21 \pm 0.9)$. However, Robinia pseudoacacia was avoided in 3 of 5 cases in this area (but D was between 0.7 and 0.8 , when it was preferred). The frequent Carpinus betulus was avoided at the same ratio $(\mathrm{D}=-0.65 \pm 0.4)$, but it was never preferred. Quercus petraea, $Q$. robur and Cornus sanguinea were always avoided by browsing animals $(\mathrm{D}=-1 \pm 0 ;-0.88 \pm 0.17 ;-1 \pm 0$, respectively).

In Zselic high preference for sycamore maple (Acer pseudoplatanus), old man's beard (Clematis vitalba) and glossy buckthorn (Frangula alnus) was detected ( $\mathrm{D}=0.82 ; 0.79$; $0.62 \pm 0.02$, respectively). Nevertheless, the first two species were present during only one season, while the last species was present in two, which could contribute to these high values. The frequent Tilia tomentosa was preferred in 2 of 5 cases and never avoided $(\mathrm{D}=0.27 \pm 0.27)$. Acer campestre also common in this area was preferred in half of the seasons ( 2 of $4, \mathrm{D}=-0.1 \pm 0.39$ ). The sparse red oak (Quercus rubra) and sometimes prevailing Rubus spp. were preferred in 2 cases and avoided in 2 cases of 5 investigations ( $\mathrm{D}=0.06 \pm 0.97 ; 0.01 \pm 0.72$, respectively). The rare European cornel (Cornus mas) $(\mathrm{D}=-0.16 \pm 1.18)$ and Rosa canina $(\mathrm{D}=-0.06 \pm 0.78)$ were also preferred in one case. Carpinus betulus and Fagus sylvatica, present in a great proportion of the understory, were almost always avoided ( 4 of 5 for both, $\mathrm{D}=-0.6 \pm 0.52$ and $-0.37 \pm 0.11$ ). Similarly, different Quercus spp. were generally avoided ( 8 of $10 ; \mathrm{D}=-0.56 \pm 0.7$ ). The rare Robinia pseudoacacia was not really preferred, but avoided only in one case ( 1 of 4 , $\mathrm{D}=0.16 \pm 0.81)$.

In Felsőtárkány the frequent Carpinus betulus and Acer spp. were preferred in only one case ( 1 of 5$)$, but never avoided ( $\mathrm{D}=0.04 \pm 0.14$ and $-0.01 \pm 0.13$, respectively). The scarcely distributed Ligustrum vulgare and blackthorn (Prunus spinosa) were also preferred on one occasion ( 1 of 5 and 1 of $3 ; \mathrm{D}=-0.02 \pm 0.24$ and $0.12 \pm 0.21$, respectively). The relatively frequent Quercus spp. were never preferred and avoided in many cases ( 3 of $5 ; \mathrm{D}=-0.08 \pm 0.13$ ).

We can state that browsing takes place on all the different woody plants of understory, not only on the main tree species (Table 3). Based on these investigations we conclude that the most preferred species were not the native target tree species of Hungarian forest management negatively affected by climate change (Fagus sylvatica, Q. petraea, Q. robur), because these species were generally avoided $(\mathrm{D}=-0.37 \pm 0.11 ;-0.79 \pm 0.56$; $-0.9 \pm 0.16$, respectively). We revealed only in a single season in Hajósszentgyörgy a preference for Quercus species. Pinus spp. were always rare and avoided almost entirely (8 of $10, \mathrm{D}=-0.57 \pm 0.79$ ). Non-native more drought-tolerant Robinia pseudoacacia was preferred irregularly, but with the highest probability among important target tree species 


\begin{tabular}{|l|lll|}
\hline & Journal : Small 10531 & Dispatch : 22-4-2013 & Pages : 14 \\
& Article No. : 490 & $\square$ LE & $\square$ TYPESET \\
MS Code : BIOC4512 & $\checkmark \mathrm{CP}$ & $\checkmark$ DISK \\
\hline
\end{tabular}

Biodivers Conserv

(preferred: 4 of 14, avoided: 5 of 14, D $=0.04 \pm 0.77$ ). Among other non-native target tree species the rare Quercus rubra was the most selected by browsing ungulates ( $\mathrm{D}=0.06 \pm 0.97$ ), but also rare Populus spp. (but not white poplar, Populus alba) were preferred in some cases $(\mathrm{D}=-0.16 \pm 0.82)$. Among those economically less or not relevant species which were found relatively frequently in the study areas the non-native Acer negundo $(\mathrm{D}=0.06 \pm 0.5)$, Celtis occidentalis $(\mathrm{D}=0.06 \pm 0.71)$ and the native Sambucus nigra $(\mathrm{D}=0.01 \pm 0.71)$, Prunus spinosa $(\mathrm{D}=-0.08 \pm 0.67)$, Rubus spp. $(\mathrm{D}=-0.12 \pm 0.58)$, Cornus sanguinea $(\mathrm{D}=-0.2 \pm 0.78)$, Acer campestre $(\mathrm{D}=-$ $0.24 \pm 0.55)$, Rosa canina $(\mathrm{D}=-0.24 \pm 0.67)$, Ligustrum vulgare $(\mathrm{D}=-0.29 \pm 0.52)$ and Corylus avellana $(\mathrm{D}=-0.43 \pm 0.86)$ were possibly preferred. Crataegus monogyna was usually avoided (17 of 24) and never preferred even if it was frequent or rare (D = $0.55 \pm 0.45)$.

\section{Discussion}

Nowadays, Robinia pseudoacacia is among the most representative invasive tree species in temperate environments (Richardson and Rejmánek 2011). The area expansion of Robinia pseudoacacia can also be witnessed throughout Hungary (Wisnovszky 2011). The excellent regeneration capability of this species in arid habitats was revealed in Hajósszentgyörgy, where this species dominated the regeneration layer of the lowland Robinia pseudoacacia forest despite its preference and intensive browsing by ungulates. Spreading of this invasive species into the near-natural forested areas is also demonstrated by our results, similarly to Austrian (Kleinbauer et al. 2010) and Italian (Benesperi et al. 2012) experiences. Robinia pseudoacacia was regularly found individually or in some small patches not only at the edges, but also in the inner parts of the hilly forested areas of Segesd (sometimes as a frequent species) and Zselic (always as a rare species). If the natural regeneration of Quercus spp. and Fagus sylvatica will be inhibited or even impossible due to the altered climatic conditions, the gaps will be occupied by more drought-tolerant invasive species like Robinia pseudoacacia. Due to its lower sensitivity to global warming effects and its ability to transform the vegetation composition by nitrogenfixation Robinia pseudoacacia can supersede native target tree species (Sitzia et al. 2012) and eliminate the characteristic shrub species of native forests (Benesperi et al. 2012). Our data in Hajósszentgyörgy showed that the prevalence of this species contributes to the appearance of other woody species indicating the degradation of the habitat (e.g. Celtis occidentalis, Ailanthus altissima or Sambucus nigra). We mention that beyond this region, e.g. in Germany, where the climate adaptation of forest owners is mainly linked to tree species choice (Milad et al. 2012), different "exotic" tree species were also reported to be planted sporadically by way of trial (e.g. Robinia pseudoacacia on extremely dry and rocky sites for the purposes of soil and slope protection).

In turn, Robinia pseudoacacia was preferred with the highest probability among important target tree species in Hungarian forests. It means that it will be affected by browsing even in the presence of other abundant and good-quality species. Since Robinia pseudoacacia is more preferred by browsing ungulates than native target tree species selective ungulate browsing becomes an important factor in forest biodiversity conservation. The browsing impact on Robinia pseudoacacia can have a fundamental suppressive effect on the penetration of this tree species into natural habitats.

According to our results Quercus spp. and Fagus sylvatica were generally avoided, while several economically non-relevant native woody species were preferred. This 


\begin{tabular}{|l|lll|}
\hline & Journal : Small 10531 & Dispatch : 22-4-2013 & Pages : 14 \\
& Article No. : 490 & $\square$ LE & $\square$ TYPESET \\
MS Code : BIOC4512 & $\checkmark \mathrm{CP}$ & $\checkmark$ DISK \\
\hline
\end{tabular}

Biodivers Conserv

324 implies that the shortage of other economically less important but more preferred shrubs or 325 juvenile trees in the feeding area of ungulates can lead to serious browsing impact on the 326 target tree species. This negative impact alone, or cumulatively with aridity process, 327 can result in remarkable decrease in the competitive ability of Quercus spp. and Fagus sylvatica against invasive drought-tolerant species, such as Robinia pseudoacacia.

Biodiversity conservation, i.e. maintaining or establishing a multi-species understory layer, can be a good solution to diminish the attractiveness of Fagus sylvatica or Quercus species. Former studies in Hungary (Mátrai and Kabai 1989; Szemethy et al. 2003b) and in other European countries (Gebert and Verheyden-Tixier 2001) have revealed unambiguously that ungulates (especially deer species) forage mainly from the understory. In a homogeneous even-aged forest with closed canopy and scarce or removed understory vegetation those herbivore species have no chance to follow their optimal food selection rules. They have to consume what they can find. In the lack of diverse understory and mixed-species plantations or regeneration sites saplings of the target tree species will necessarily be exposed to an increased browsing effect even in cases of only moderate herbivore pressure.

According to our preference analyses, potential species for diverting the browsing pressure from the target tree species can be Rubus spp., Sambucus nigra, Prunus spinosa, Cornus sanguinea, Acer campestre, Rosa canina, Ligustrum vulgare and Corylus avellana. Our results are consistent with the findings in a French study (Boulanger et al. 2009), where Fagus sylvatica and Quercus spp. were classified among the avoided species, meanwhile Cornus spp., Rosa arvensis, Rubus fruticosus and Ligustrum vulgare appeared among the most selected species.

Deer initially feed mainly on the most preferred foods, but become far less selective as deer density increases. Therefore, a reduction of deer population would reduce browsing pressure on forest vegetation in consecutive steps, firstly on avoided woody species, later on preferred ones (Nugent 1990). Therefore, when ungulates show selectivity to species generally avoided, we can suppose that ungulate population is actually "overabundant" and/or understory food supply is scarce, generally preferred woody species are not available. Although there were great differences in the reported ungulate densities among our study areas (red deer density ranged between 3.48 and 13.62 estimated or 2.24 and 5.59 shot individuals/100 ha), a clear browsing preference to Fagus sylvatica or Quercus petraea and $Q$. robur was never revealed. It suggests that ungulate density in our study areas still has not reached the level where browsing selection is entirely suppressed by feeding competition. However, it does not necessarily mean that it would not cause a regeneration failure of those woody species, which actually become less resistant to herbivory, e.g. the abovementioned target tree species suffering from increasing aridity. Although the reported density data are not reliable enough for a scientific analysis, we note that some of the model simulations conclude that there are relatively small differences in the effects of the ungulates on natural forest regeneration at very low to very high densities (Kramer et al. 2006).

The habitat changes currently taking place in the Pannon region and the processes in the future will presumably increase the expansion of large game species in Hungary. According to our earlier dietary studies in Hajósszentgyörgy, Robinia pseudoacacia can be an important component of red deer diet (Mátrai et al. 2004). The excellent quality (high crude protein content) of Robinia pseudoacacia foliage (and that of also preferred Sambucus nigra appearing in nitrogen-rich soils under Robinia pseudoacacia trees) means suitable and abundant food supply for red deer (Szemethy et al. 2003b). Furthermore, the expansion of deer is not expected to be concentrated only within newly afforested areas 


\begin{tabular}{|l|lll|}
\hline & Journal : Small 10531 & Dispatch : 22-4-2013 & Pages : 14 \\
Article No. : 490 & $\square$ LE & $\square$ TYPESET \\
MS Code : BIOC4512 & $\checkmark \mathrm{CP}$ & $\checkmark$ DISK \\
\hline
\end{tabular}

Biodivers Conserv

occupied by Robinia pseudoacacia, but also to the neighbouring agricultural areas (Biró et al. 2006; Szemethy et al. 2003a). Therefore, red deer will have impact not only on forest vegetation, but also on agricultural crops (Bleier et al. 2012).

Area expansion of Robinia pseudoacacia will presumably be accompanied by the spreading of red deer. Because of the expanding ungulate populations, the amount of compensation paid for forest and agricultural game damage will probably increase, but at the same time increasing hunting incomes to game management units will be also ensured. Consequently, the management goal is to keep population density at acceptable and damage at tolerable levels (Csányi and Lehoczki 2010). In any case, the maintained ungulate density will influence the joint effects of climate change and large herbivores on the vegetation. Selective browsing pressure on tree or shrub species at a given ungulate density will depend on the actual species composition of the understory, which will be determined by climate change impacts and forest management practices.

\section{Conclusions}

Better understanding of the regulatory impacts of large herbivores in forest ecosystems and biodiversity conservation under climate change is a difficult challenge. Diverse unevenaged forest ecosystems will probably be more resistant to climate change effects (Milad et al. 2012). Fortunately, transformation of Hungarian even-aged forests to uneven-aged ones has already started in the last decade. We expect the various plant species composition of the understory to provide the basis of preferential foraging of forest-dwelling ungulates. Our studies in Hungarian even-aged forests revealed that a moderate selective ungulate browsing should not have an additional negative impact on the regeneration of native more drought-sensitive Fagus sylvatica and Quercus spp. due to general avoidance by large herbivores in a habitat with diverse understory vegetation. However, the long-term sustainability of forests dominated by drought-sensitive native species depends also on the chance of non-native more drought-tolerant species to penetrate into these areas. The described browsing preference order indicates that the expansion of non-native, more drought-tolerant Robinia pseudoacacia preferred by ungulates could be decelerated by an intensive herbivory impact. But in this unpredictable period of climate change continuous cooperation of forest and game management and their integrated approach to forest vegetation dynamics and ungulate-vegetation interactions would be essential to keep Quercus and Fagus forests resistant against Robinia pseudoacacia.

Acknowledgements We are grateful to Katalin Mátrai, Zsolt Biró and the other colleagues and students for participating in field works. Zoltán Somogyi provided us valuable comments and information. James Dedon revised the final English version of the manuscript. The Gemenc, SEFAG Forestry and Timber Industry and Egererdő joint-stock companies made the investigations possible on their areas. The work was funded by the Game Management Foundation of the Ministry of Agriculture and Rural Development (FVM 73028/2002). This paper was supported by the János Bolyai Research Scholarship of the Hungarian Academy of Sciences (to Katona, K.) and the Research Faculty Grant of the Hungarian Ministry of Human Resources (7629-24/2013/TUDPOL).

\section{References}

Apollonio M, Andersen R, Putman R (2010) Present status and future challenges for European ungulate management. In: Apollonio M, Andersen R, Putman R (eds) European ungulates and their management in the 21st century. Cambridge University Press, Cambridge, pp 578-604 


\begin{tabular}{|l|llll|}
\hline & Journal : Small 10531 & Dispatch : $22-4-2013$ & Pages : 14 \\
& Article No. : 490 & $\square$ LE & $\square$ TYPESET \\
\hline
\end{tabular}

Biodivers Conserv

418

419

420

421

422

423

424

425

426

427

428

429

430

431

432

433

434

435

436

437

438

439

440

441

442

443

444

445

446

447

448

449

450

451

452

453

454

455

456

457

458

459

460

461

462

463

464

465

466

467

468

469

470

471

472

473

474

475

476

477
Barrett RP, Mebrahtu T, Hanover JW (1990) Black locust: a multi-purpose tree species for temperate climates. In: Janick J, Simon JE (eds) Advances in new crops. Timber Press, Portland OR, pp 278-283

Benesperi R, Giuliani C, Zanetti S, Gennai M, Lippi MM, Guidi T, Nascimbene J, Foggi B (2012) Forest plant diversity is threatened by Robinia pseudoacacia (black-locust) invasion. Biodivers Conserv 21:3555-3568

Berki I, Rasztovits E, Móricz N, Mátyás Cs (2009) Determination of the drought tolerance limit of beech forests and forecasting their future distribution in Hungary. Cereal Res Commun 37:613-616

Biró Zs, Szemethy L, Katona K, Heltai M, Pető Z (2006) Seasonal distribution of red deer (Cervus elaphus) in a forest-agriculture habitat in Hungary. Mammalia 70(1-2):70-75

Bleier N, Lehoczki R, Újváry D, Szemethy L, Csányi S (2012) Relationships between wild ungulates density and crop damage in Hungary. Acta Theriol 57(4):351-359

Boulanger V, Baltzinger C, Saïd S, Ballon P, Picard J-F, Dupouey J-L (2009) Ranking temperate woody species along a gradient of browsing by deer. For Ecol Manage 258:1397-1406

Burbaité L, Csányi S (2009) Roe deer population and harvest changes in Europe. Est J Ecol 58(3):169-180

Byers CR, Steinhorst RK, Krausman PR (1984) Clarification of technique for analysis of utilizationavailability data. J Wildl Manage 48:1050-1053

Cairns DM, Moen J (2004) Herbivory influences tree lines. J Ecol 92:1019-1024

Côté SD, Rooney TP, Tremblay J-P, Dussault C, Waller DM (2004) Ecological impacts of deer overabundance. Annu Rev Ecol Evol Syst 35:113-147

Cs Mátyás, Vendramin GG, Fady B (2009) Forests at the limit evolutionary-genetic consequences of environmental changes at the receding (xeric) edge of distribution. Ann For Sci 66:800-803

Csányi S, Lehoczki R (2010) Ungulates and their management in Hungary. In: Apollonio M, Andersen R, Putman R (eds) European ungulates and their management in the 21st century. Cambridge University Press, Cambridge, pp 291-318

Czúcz B, Gálhidy L, Mátyás C (2011) Present and forecasted xeric climatic limits of beech and sessile oak distribution at low altitudes in Central Europe. Ann For Sci 68(1):99-108

Didion M, Kupferschmid AD, Wolf A, Bugmann H (2011) Ungulate herbivory modifies the effects of climate change on mountain forests. Clim Chang 109:647-669

FVM (Ministry of Agriculture and Rural Development) (2008) A Nemzeti Erdőprogram 2006-2015. évi megvalósításának terve a Kormány 1110/2004. (X. 27.) Korm. határozatának 3. pontja alapján. Ministry of Agriculture and Rural Development, Budapest (In Hungarian)

Gálos B, Lorenz Ph, Jacob D (2008) Will dry events occur more often in Hungary in the future? Environ Res Lett 2:034006

Gebert C, Verheyden-Tixier H (2001) Variations of diet composition of red deer (Cervus elaphus L.) in Europe. Mammal Rev 31(3):189-201

Gill RMA, Beardall V (2001) The impact of deer on woodlands: the effects of browsing and seed dispersal on vegetation structure and composition. Forestry 74(3):209-218

Herrero A, Zamora R, Castro J, Hódar JA (2012) Limits of pine forest distribution at the tree line: herbivory matters. Plant Ecol 213:459-469

IPCC (2007) Summary for policymakers. In: Solomon S, Qin D, Manning M, Chen Z, Marquis M, Averyt KB, Tignor M, Miller HL (eds) Climate change 2007: the physical science basis. contribution of working group I to the fourth assessment report of the intergovernmental panel on climate change. Cambridge University Press, Cambridge, pp 1-18

Jacobs J (1974) Quantitative measurement of food selection. A modification of the forage ratio and Ivlev's electivity index. Oecologia 14:413-417

Kauhala H, Auttila M (2010) Estimating habitat selection of badgers - a test between different methods. Folia Zool 59(1):16-25

Kleinbauer I, Dullinger S, Peterseil J, Essl F (2010) Climate change might drive the invasive tree Robinia pseudacacia into nature reserves and endangered habitats. Biol Conserv 143(2):382-390

Kramer K, Groot Bruinderink GWTA, Prins HHT (2006) Spatial interactions between ungulate herbivory and forest management. For Ecol Manage 226:238-247

Lakatos F, Molnár M (2009) Mass mortality of beech on Southwest Hungary. Acta Silvatica et Lignaria Hungarica 5:75-82

Mátrai K, Kabai P (1989) Winter plant selection by red and roe deer in a forest habitat in Hungary. Acta Theriol 34:227-234

Mátrai K, Katona K, Szemethy L, Orosz Sz (2002) Quantitative and qualitative characteristics of red deer diet during vegetation period in a lowland forest, Hungary. Vadbiológia 9:1-10 (In Hungarian with an English summary)

Mátrai K, Szemethy L, Tóth P, Katona K, Székely J (2004) Resource use by red deer in lowland nonnative forests, Hungary. J Wildl Manage 68:879-888 


\begin{tabular}{|l|lll|}
\hline & Journal : Small 10531 & Dispatch : 22-4-2013 & Pages : 14 \\
& Article No. : 490 & $\square$ LE & $\square$ TYPESET \\
MS Code : BIOC4512 & $\checkmark \mathrm{CP}$ & $\checkmark$ DISK \\
\hline
\end{tabular}

Biodivers Conserv

Mátyás Cs (2010) Forecasts needed for retreating forests (opinion). Nature 464:1271

Mátyás Cs, Czimber K (2000) Modelling of zonal forest cover: possibilities for forecasting climate change effects. In: Kircsi A (ed) Third conference on forest and climate. Kossuth University Press, Debrecen, pp 83-97 (In Hungarian with an English summary)

Milad M, Schaich H, Bürgi M, Konold W (2011) Climate change and nature conservation in Central European forests: a review of consequences, concepts and challenges. For Ecol Manag 261:829-843

Milad M, Schaich H, Konold W (2012) How is adaptation to climate change reflected in current practice of forest management and conservation? A case study from Germany. Biodivers Conserv. doi: 10.1007/s10531-012-0337-8

Milner JM, Bonenfant C, Mysterud A, Gaillard JM, Csányi S, Stenseth NC (2006) Temporal and spatial development of red deer harvesting in Europe: biological and cultural factors. J Appl Ecol 43:721-734

Neu CV, Byers CR, Peek JM (1974) A technique for analysis of utilization-availability data. J Wildl Manage 38(3):541-545

Nugent G (1990) Forage availability and the diet of fallow deer (Dama dama) in the Blue Mountains, Otago. New Zeal J Ecol 13:83-95

Putman RJ, Moore NP (1998) Impact of deer in lowland Britain on agriculture, forestry and conservation habitats. Mammal Rev 28(4):141-164

Richardson DM, Rejmánek M (2011) Trees and shrubs as invasive alien species—a global review. Divers Distrib 17:788-809

Scientific Expert Group on Climate Change (SEG) (2007) In: Bierbaum RM, Holdren JP, MacCracken MC, Moss RH, Raven PH (eds) Confronting climate change: avoiding the unmanageable and managing the unavoidable. Report prepared for the United Nations Commission on sustainable development. Sigma $\mathrm{Xi}$, Research Triangle Park and the United Nations Foundation, NC and Washington, DC

Sitzia T, Campagnaro T, Dainese M, Cierjacks A (2012) Plant species diversity in alien black locust stands: a paired comparison with native stands across a north-Mediterranean range expansion. For Ecol Manag 285:85-91

Szemethy L, Mátrai K, Biró Zs, Katona K (2003a) Seasonal home range shift of red deer in a forestagriculture area in southern Hungary. Acta Theriol 48:547-556

Szemethy L, Mátrai K, Katona K, Orosz Sz (2003b) Seasonal home range shift of red deer hinds Cervus elaphus: are there feeding reasons? Folia Zool 52(3):249-258

Winnett SM (1998) Potential effects of climate change on U.S. forests: a review. Clim Res 11:39-49

Wisnovszky K (ed) (2011) Forest resources, forestry and wood management in Hungary. Central Agricultural Office, Forest Directorate, Budapest 